\title{
Phonological Processing and Reading and Writing Skills in Literacy ${ }^{1}$
}

\author{
Gabriela Guarnieri Mendes² \\ Universidade de São Paulo, Ribeirão Preto-SP, Brazil
}

\author{
Sylvia Domingos Barrera \\ Universidade de São Paulo, Ribeirão Preto-SP, Brazil
}

\begin{abstract}
Studies suggest the influence of phonological processing on literacy, although there is controversy about the cognitive skills underlying this construct. This study investigated the contribution of phonological awareness, phonological memory, rapid naming and visual processing in reading and writing performance of a sample of 50 students of the 3rd grade of an Elementary Public School. The results indicated that phonological awareness and phonological memory are the skills that contributed most to the initial performance in reading and writing. In respect of rapid naming, only the letters naming showed significant correlation with reading and writing and there was no correlation between visual processing and reading or writing. The exploratory factor analysis suggested the grouping of variables in three factors, the first formed by the phonological memory and phonological awareness, the second formed by the rapid naming and the third by the visual processing.
\end{abstract}

Keywords: phonological awareness, working memory, reading, handwriting

\section{Processamento Fonológico e Habilidades de Leitura e de Escrita na Alfabetização}

\begin{abstract}
Resumo: Estudos sugerem a influência do processamento fonológico sobre a alfabetização, embora haja controvérsias sobre as habilidades cognitivas subjacentes a esse constructo. Este estudo investigou a contribuição da consciência fonológica, memória de trabalho fonológica, nomeação rápida e processamento visual no desempenho em leitura e escrita de uma amostra de 50 alunos do $3^{\circ}$ Ano do Ensino Fundamental de uma escola pública. Os resultados indicaram que a consciência fonológica e a memória de trabalho fonológica são as habilidades que mais contribuem para o desempenho inicial em leitura e escrita. Quanto às habilidades de nomeação rápida, apenas a nomeação de letras apresentou correlação significativa com a leitura e escrita, não havendo correlação destas últimas com o processamento visual. A análise fatorial exploratória sugeriu o agrupamento das variáveis estudadas em três fatores, o primeiro formado pela memória de trabalho fonológica e consciência fonológica, o segundo, pela nomeação rápida e o terceiro, pelo processamento visual.
\end{abstract}

Palavras-chave: consciência fonológica, memória operacional, leitura, escrita

\section{Procesamiento Fonológico y Habilidades de Lectura y Escritura en la Alfabetización}

\begin{abstract}
Resumen: Estudios sugieren la influencia del procesamiento fonológico en la alfabetización, aunque existen controversias sobre las habilidades cognitivas subyacentes a este constructo. Este estudio investigó la contribución de la conciencia fonológica, memoria fonológica, denominación rápida y procesamiento visual en la lectura y escritura de una muestra de 50 estudiantes de tercer año en una escuela primaria pública. Los resultados indicaron que la conciencia fonológica y la memoria fonológica son las habilidades que mas contribuyen al rendimiento inicial en la lectura y la escritura. En cuanto a la denominación rápida, sólo la denominación de letras mostró correlación significativa con la lectura y la escritura, pero no hubo correlación de estas habilidades con el procesamiento visual. El análisis factorial exploratorio sugiere la agrupación de las variables en tres factores, el primero formado por la memoria fonológica y la conciencia fonológica, el segundo por la denominación rápida y el tercero por el procesamiento visual.
\end{abstract}

Palabras clave: conciencia fonológica, memoria operacional, lectura, escritura manual

Reading and writing are fundamental instruments for life in literate societies. The academic, professional and even the autonomy success of an individual largely relies on their ability to read and write. However, these skills are

\footnotetext{
${ }^{1}$ Article derived from the Master's thesis of the first author under the supervision of the second author, defended in 2015, in the Graduate Program in Psychology of the Faculdade de Filosofia, Ciências e Letras de Ribeirão Preto, Universidade de São Paulo.

Support: Coordination of Improvement of Higher Level Personnel (CAPES) ${ }^{2}$ Correspondence address:

Gabriela Guarnieri Mendes. Rua Adolfo Pontonico, $\mathrm{n}^{\circ}$ 37, Centro. CEP 14640-000. Morro Agudo-SP, Brazil. E-mail: gabiigm@yahoo.com.br
}

not acquired spontaneously; they rely on cognitive skills and knowledge that depend on a directed and systematic intervention in order to be developed. Over the last 40 years, a wide range of Cognitive Psychology research has suggested the existence of predictor variables of reading and writing performance. Among these variables, we find phonological awareness, phonological memory and rapid naming, also called phonological processing skills (C.N.G. Justi, Roazzi, F.R. Justi, Henriques, \& Cançado, 2014; Melby-Lervag, Lyster, \& Hulme, 2012; Wagner \& Torgesen, 1987). Phonological processing refers to the conscious use of phonological information (sounds of a given language) in 
the speech and writing processing. This processing is related to mental processing of information treatment based on oral phonological structure (Wagner \& Torgesen, 1987).

Phonological awareness is defined as the skills to reflect and manipulate speech sounds, encompassing the skill to operate with rhymes, alliterations, syllables, and phonemes. This skill has different levels, ranging from a "superficial" sensitivity of larger phonological units to a "deep" sensitivity of small phonological units (Cunha \& Capellini, 2011). Several studies have shown that metaphonological skills relate to success in learning to read and write (Barrera \& Maluf, 2003; Justino \& Barrera, 2012; Melby-Lervag et al., 2012).

Phonological memory has also been considered in the literature as largely related to reading skills (Kibby, Marks, Morgan, \& Long, 2004; Wagner \& Torgesen, 1987) and phonological awareness (Melby-Lervag et al., 2012). According to the model proposed by Baddeley and Hitch (cited by Gathercole \& Baddeley, 1993), the working memory would have two support systems, responsible for processing and maintaining information in the short-term memory, one of phonological and another of visuospatial nature. According to Wagner and Torgesen (1987), the efficiency in phonetic coding and its temporary maintenance in the memory assist the reader to apply the maximum of their cognitive resources to connect isolated phonemes in order to form words. For the authors, there is considerable evidence that good and bad readers vary in terms of their efficiency in phonetic recoding in working memory, which manifests in verbal memory span tasks, whose performance is relatively independent of general cognitive skills.

Snowling and Stackhouse (2004) consider that the skills to repeat words and pseudowords offer information about the phonological processing proficiency, particularly with regard to phonological memory. During repetition, the children rely less on their own phonological representations, since the examiner provides the stimulus.

In addition to phonological awareness and phonological memory, there is evidence that a third cognitive skill is also important for reading, the rapid automatized naming (RAN). Recent studies suggest that the skills to process and name visual symbols quickly and correctly plays an important role in learning to read, and a disorder in these skills can lead to learning deficits (Capellini \& Lanza, 2010; Germano, Pinheiro, Padula, Lorencetti, \& Capellini, 2012). Naming speed is also largely related to the speed of access to longterm memory and to phonological naming, which may influence the development of reading and writing (Bicalho \& Alves, 2010).

The literature has conflicting conceptions about the naming speed nature: Wagner and Torgesen (1987) suggest that this skill is primarily related to phonological processing, whereas Wolf and Bowers (1999) believe that naming speed is linked to accuracy, automaticity and synchrony of a set of perceptive (discrimination and identification of visual patterns), lexical (recovery of phonological information) and motor processes (related to speech articulation).

According to Wagner and Torgesen (1987), phonological recoding in the access to the lexicon has its importance in the reading evidenced by the speed differences in naming colors, objects, letters and digits, observed between normal and dyslexic readers. However, there is no evidence of causal relationships between naming speed and reading acquisition.

Wolf and Bowers (1999) suggested the existence of three subtypes of difficulties in reading: the first, originating from deficits in phonological skills; the second, caused by slowness in naming visual patterns, which interferes with spelling processing and reading fluency; and the third, caused by the combination of the two previous subtypes. According to this theory, a disorder in the skill to process visual symbols quickly would constitute a second deficit in dyslexia, regardless of phonemic awareness deficit. This hypothesis reintroduces the idea of visual processing as an important variable to be considered in learning of reading.

In a recent study, C.N.G. Justi, Roazzi and F.R. Justi (2014) compared the two theoretical proposals: Wagner and Torgesen (1987) versus Wolf and Bowers (1999), through structural equation modeling, assessing phonological awareness, phonological memory and rapid naming skills in a sample of Brazilian children enrolled in the 4th year of Elementary School. The results of that study suggest that the best way to conceptualize the relationship between phonological awareness, phonological memory and rapid naming scores, and the constructs underlying them is through a two-factor model, where rapid naming represents a separate factor of the "phonological processing" factor, thus corroborating Wolf and Bowers' hypothesis (1999). Despite the results, C.N.G. Justi, Roazzi and F.R. Justi (2014) state that this study provides only evidence that the basic nature of these processes is not phonological, suggesting new studies to determine more precisely the nature of the psychological processes underlying rapid naming.

Considering the questions in the scientific literature regarding the cognitive skills underlying phonological processing and the relevance of the theme to the understanding of the cognitive processes involved in learning of reading and writing, this study aimed to (1) analyze the contribution of the different cognitive skills considered representative of the phonological processing - Phonological Awareness, Phonological Memory and Rapid Naming - added of Visual Processing skill, for initial reading and writing learning; (2) to analyze the correlation pattern between these skills. As main hypotheses of the study, the expectation is that (a) all studied skills are correlated to reading and writing performance, with emphasis on phonological awareness as the main predictor of this performance; (b) tests of memory of pseudowords and RAN letters, depending on the nature of the used stimuli, are the best predictors of reading and writing performance among phonological memory and rapid naming tasks.

\section{Method}

\section{Participants}

Fifty children of both sexes (26 females and 24 males), students of the 3rd Year of Elementary School, from a public school in the countryside of São Paulo participated in this 
study. Participants had a mean age of 7 years and 7 months ( $S D=0.443$ months). The sample, selected by convenience, was characterized by children who have not failed any year at school, with no complaints of hearing or visual problems and presenting oral language within normality patterns. The school staff provided this information and the children's language was observed during the application of the research tests.

\section{Instruments}

Phonological Awareness Test: Sequential Assessment Instrument (CONFIAS, in Portuguese). Elaborated and standardized in Brazil by Moojen et al., (2007), this instrument is composed of tasks of synthesis, segmentation, identification, production, exclusion and transposition, at the syllabic and phonemic levels. Each correct answer equals one point and each incorrect answer is zero, with 70 being the total number of possible hits.

Auditory Sequential Memory Subtest of the Illinois Test of Psycholinguistic Abilities - ITPA, with Brazilian adaptation by Bogossian and Santos (1977), has standards for children from 2 to 10 years-old, in addition to presenting evidence of validity and reliability, being used to evaluate phonological memory.

Test of Words and Pseudowords Repetition (TRPP, in Portuguese) (Seabra \& Dias, 2012), based on the test of Gathercole and Baddeley (1993), used to evaluate the phonological memory by remembering words and pseudowords.

The Rapid Automatized Naming Test - RAN, developed by Denckla and Rudel (1974) and adapted by Ferreira, Capellini, Ciasca and Tonelotto (2003), includes the subtests of letters, numbers, colors and objects naming. The time each participant spends to complete the test (to name all stimuli) is recorded in seconds. Therefore, in this case a better performance corresponds to a lower score.

Test of Writing with Dictation, reduced version (Seabra, Dias, \& Capovilla, 2013), composed of 36 items, of which 24 are words and 12 are pseudowords; 18 are disyllable and 18 are trisyllable. The Test is standardized for children from 7 to 11 years-old and shows validity evidence based on correlations with other tests and with the school grade.

Test of Reading Words and Pseudowords, PROLEC, Brazilian adaptation by Capellini, Oliveira and Cuetos (2010), used to assess reading through a list of 60 stimuli with 40 words and 20 pseudowords. The test has standards from the $2^{\text {nd }}$ to the $5^{\text {th }}$ grade and validity studies prove its effectiveness in differentiating children with and without learning difficulties.

Evolutional Test of Visual Perception, DTVP-2 (Hammil, Pearson, \& Voress, 2001). It is used to evaluate visual processing skills through position in space; figure background; visual closure and shape constancy subtests. The gross score of each subtest was converted into a standard score, which was added, generating a total standard score for the "visual processing" skill.

\section{Procedure}

Data collection. We collected all data at the school, in a quiet room, which the researcher was allowed to use during the normal class period. The tests were administered in individual sessions, lasting about 30 to 40 minutes and occurred in two sessions, to avoid fatigue interfering with the participants' performance.

Data analysis. We analyzed the data quantitatively through correlation techniques, regression analysis and exploratory factor analysis using the Statistical Package for Social Sciences (SPSS) program, version 17.0. Based on indications from authors such as Cohen (1988) and Evans (1996), we considered strong correlations as values between .70 and 1 ; moderate values between .30 and .69; and weak values between 0 and 29 .

\section{Ethical Considerations}

The Research Ethics Committee of the School of Philosophy, Sciences and Language of Ribeirão Preto approved this study (CAAE $n^{\circ}$ 23545013.0.0000.5407). The legal responsible for the participants signed the Free and Clarified Consent Term and the students signed the Term of Assent.

\section{Results}

Table 1 shows the matrix of correlations obtained between the studied variables. From these results, multiple regression analysis was calculated to identify which predictor variables contribute most to explain the results obtained in the Reading and Writing tests. The Stepwise was the methodology we used in the regression analysis, inserting in the calculations only the predictor variables that showed a significant correlation with the criteria variables $(p<.05)$.

Initially, we performed previous statistical analysis that allowed us to reject the multicollinearity hypothesis (very high correlation) between the predictor variables, which is an important criterion for using regression analysis. To explain the variability in Writing performance, we initiated regression analysis considering all predictor variables significantly correlated with performance in the Writing test: Memory of Pseudowords, RAN letters, Phonological Awareness' syllables, Phonological Awareness' phonemes and Total Phonological Awareness (Table 1). From that, we proceeded by excluding from the model the variables that, in the successive analyzes, did not present statistical significance, obtaining as final result the model that included only the total PA and Memory of pseudowords variables, in which both predictor variables showed significance (Table 2). This model explained about $60 \%$ of the performance variability observed in Writing. 
Table 1

Matrix of Correlations (Pearson) Between the Studied Variables

\begin{tabular}{|c|c|c|c|c|c|c|c|c|c|c|c|c|c|}
\hline & Writing & Reading & $\begin{array}{l}\text { Memory } \\
\text { Pseudow. }\end{array}$ & $\begin{array}{c}\text { Memory } \\
\text { Word }\end{array}$ & $\begin{array}{c}\text { Memory } \\
\text { Digit }\end{array}$ & $\begin{array}{l}\text { RAN } \\
\text { Color }\end{array}$ & $\begin{array}{l}\text { RAN } \\
\text { Letter }\end{array}$ & $\begin{array}{l}\text { RAN } \\
\text { Digit }\end{array}$ & $\begin{array}{c}\text { RAN } \\
\text { Object }\end{array}$ & $\begin{array}{c}\text { PA } \\
\text { Syllable }\end{array}$ & $\begin{array}{c}\text { PA } \\
\text { Phoneme }\end{array}$ & $\begin{array}{c}\text { PA } \\
\text { Total } \\
\end{array}$ & $\begin{array}{l}\text { Visual } \\
\text { Proc }\end{array}$ \\
\hline Writing & 1 & $.718^{* *}$ & $.417^{* *}$ & .060 & .252 & -.252 & $-.414^{* *}$ & -.269 & -.135 & $.620^{* *}$ & $.636^{* *}$ & $.739^{* *}$ & .059 \\
\hline Reading & $.718^{* *}$ & 1 & $.286^{*}$ & .201 & .051 & -.196 & $-.373^{* *}$ & -.263 & -.110 & $.359^{*}$ & $.389^{* *}$ & $.484^{* *}$ & .090 \\
\hline $\begin{array}{l}\text { Mem. } \\
\text { Pseud. }\end{array}$ & $.417^{* *}$ & $.286^{*}$ & 1 & .226 & $.415^{* *}$ & -.086 & -.008 & .067 & .054 & .178 & .181 & .209 & .023 \\
\hline Mem. Word & .060 & .201 & .226 & 1 & .071 & -.084 & -.097 & -.019 & -.205 & .176 & -.116 & .061 & .155 \\
\hline Mem. Digit & .252 & .051 & $.415^{* *}$ & .071 & 1 & -.092 & -.032 & .005 & .048 & $.325^{*}$ & $.346^{*}$ & $.409^{* *}$ & .063 \\
\hline RAN Color & -.252 & -.196 & -.086 & -.084 & -.092 & 1 & $.571^{* *}$ & $.655^{* *}$ & $.445^{* *}$ & -.146 & $-.332^{*}$ & -.273 & -.087 \\
\hline RAN Letter & $-.414^{* *}$ & $-.373^{* *}$ & -.008 & -.097 & -.032 & $.571^{* *}$ & 1 & $.762^{* *}$ & $.641^{* *}$ & $-.360^{*}$ & $-.352^{*}$ & $-.395^{* *}$ & -.104 \\
\hline RAN Digit & -.269 & -.263 & .067 & -.019 & .005 & $.655^{* *}$ & $.762^{* *}$ & 1 & $.680^{* *}$ & -.179 & -.200 & -.234 & -.028 \\
\hline RAN Object & -.135 & -.110 & .054 & -.205 & .048 & $.445^{* *}$ & $.641^{* *}$ & $.680^{* *}$ & 1 & -.163 & -.041 & -.088 & -.121 \\
\hline PA Syllable & $.620^{* *}$ & $.359^{*}$ & .178 & .176 & $.325^{*}$ & -.146 & $-.360^{*}$ & -.179 & -.163 & 1 & $.500^{* *}$ & $.799^{* * *}$ & .229 \\
\hline $\begin{array}{l}\text { PA } \\
\text { Phoneme }\end{array}$ & $.636^{* *}$ & $.389^{* *}$ & .181 & -.116 & $.346^{*}$ & $-.332^{*}$ & $-.352^{*}$ & -.200 & -.041 & $.500^{* *}$ & 1 & $.875^{* *}$ & .244 \\
\hline PA Total & $.739^{* *}$ & $.484^{* *}$ & .209 & .061 & $.409^{* *}$ & -.273 & $-.395^{* *}$ & -.234 & -.088 & $.799^{* *}$ & $.875^{* *}$ & 1 & $.292^{*}$ \\
\hline Vis.Proc. & .059 & .090 & .023 & .155 & .063 & -.087 & -.104 & -.028 & -.121 & .229 & .244 & $.292^{*}$ & 1 \\
\hline
\end{tabular}

Note. $\mathrm{RAN}=$ Rapid Automatized Naming. PA $=$ Phonological Awareness; $* p<.05 ; * * p<.01$.

Table 2

Results of Regression Analysis and Coefficients of explanation of Writing and Reading Performance, Considering the Significant Predictor Variables

\begin{tabular}{|c|c|c|c|c|c|c|c|}
\hline Model-Writing & $\mathrm{B}$ & Standard Error & Beta & $\mathrm{t}$ & Sig. & $\mathrm{R}^{2}$ & $\mathrm{R}^{2}$ adjusted \\
\hline (Constant) & -23.216 & 5.118 & & -4.536 & .000 & .618 & .601 \\
\hline PA Total & .678 & .092 & .681 & 7.385 & .000 & & \\
\hline Mem. pseudow. & 2.224 & .746 & .275 & 2.980 & .005 & & \\
\hline Model-Reading & B & Standard Error & Beta & $\mathrm{t}$ & Sig. & $\mathrm{R}^{2}$ & $\mathrm{R}^{2}$ adjusted \\
\hline (Constant) & 24.908 & 6.937 & & 3.591 & .001 & .234 & .218 \\
\hline PA Total & .472 & .123 & .484 & 3.833 & .000 & & \\
\hline
\end{tabular}

Afterwards, the same methodology was used to identify the predictor variables that best explain the Reading performance of the studied sample, inserting in the regression analysis the predictor variables significantly correlated with this skill: Memory of pseudowords, RAN letters, PA syllables, PA phonemes and PA total. By excluding successively from the analysis the variables that lack from showing statistical significance, we obtained the model presented in Table 2, which includes only the PA total variable, which explains about $22 \%$ of the variation in Reading.

Analyzing more closely the pattern of significant correlations between predictor variables (Table 1), there were strong correlations between RAN letters and RAN digits, as well as between PA total and their partial scores of PA syllables and PA phonemes. These last two variables, in turn, presented moderate correlation between themselves. Moderate correlations were also found between Memory of Digits and Memory of Pseudowords, as well as between Memory of Digits and the other PA scores. As expected, the four RAN measures correlated significantly with each other; however, few correlations occurred with the other variables. The exceptions were RAN letters, which moderately correlated negatively with PA syllables, PA phonemes, PA total and RAN color, which correlated negatively with PA phonemes. Visual processing weakly correlated only with PA total.

Finally, to more directly test the possibility of grouping the variables considered as predictor of reading and writing, we performed an exploratory factor analysis based on the obtained results. For this analysis we considered the following predictor variables: Total memory (words + pseudowords), Memory of digits, RAN letters, RAN digits, RAN color, RAN objects, PA total and Visual processing. The appropriateness criteria of the sample to use this technique were reached $(\mathrm{KMO}=0.71$ indicates that the data have reasonable appropriateness for the method and Bartlett Test with $p=.00$ rejects the hypothesis of the correlation matrix being an identity matrix, allowing analysis).

The extraction of the number of factors followed the criterion of using ScreePlot (Figure 1), identifying the point where the graphic starts to be horizontal as indicative of the maximum number of factors to be extracted. Thus, three factors were considered for the analysis. 
Scree Plot

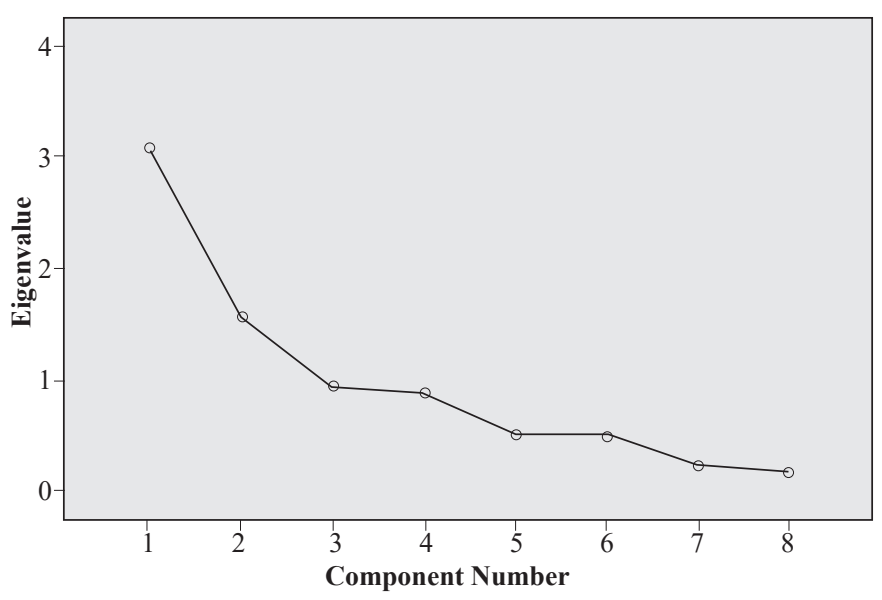

Figure 1. Exploratory Factor Analysis: Extraction of Factors.

Table 3 shows that, considering the extracted factors, explaining about $70 \%$ of the variance of the results is possible, being $36.69 \%$ of the variance explained by Factor 1, 19.09\% by Factor 2 and $14.24 \%$ by Factor 3. Table 3 also contains the analyzed variables and the "load" of each of them on each of the extracted factors, already corrected from the Varimax rotation. The factorial rotation aims to find a simpler and more interpretable solution, in which each variable shows high factorial load in a few factors, or in only one (Abdi, 2003, as cited by Damásio, 2012). Therefore, we can conclude that Factor 1 is more "loaded" of the variables RAN digits, RAN letters, RAN objects and RAN colors, Factor 2 of the variables Memory digits, Total memory and PA total and Factor 3, of the variable Visual Processing.

Table 3

Matrix of Components subjected to Varimax rotation and its respective factorial loads

\begin{tabular}{lccc}
\hline & Factor 1 & Factor 2 & Factor 3 \\
\hline RAN digits & $\mathbf{. 9 2 4}$ & .012 & .012 \\
RAN letters & $\mathbf{. 8 7 7}$ & -.106 & -.120 \\
RAN objects & $\mathbf{. 8 0 9}$ & .068 & -.063 \\
RAN color & $\mathbf{. 7 6 4}$ & -.175 & -.024 \\
Memory Digits & .043 & $\mathbf{. 8 6 0}$ & -.019 \\
Total memory & -.037 & $\mathbf{. 6 1 7}$ & .019 \\
PA Total & -.266 & $\mathbf{. 6 0 0}$ & .447 \\
Visual processing & -.027 & .036 & $\mathbf{. 9 5 9}$ \\
Eigenvalue & 3.071 & 1.574 & .958 \\
\%variance explained & 36.696 & 19.092 & 14.241 \\
\%variance cumulative & 36.696 & 55.788 & 70.029 \\
\hline Note: Values in bold refer & to &
\end{tabular}

Note: Values in bold refer to the factors grouping.

\section{Discussion}

The main objective of this study was to analyze the relationship between the different cognitive skills generally consideredas involved in phonological processing-phonological awareness, phonological memory, rapid automatized naming (RAN), also analyzing the possible contribution of each of them and of visual processing for reading and writing performance of students in the literacy process.

According to the correlation and multiple regression analyzes, the model that best explains the writing variation includes the total Phonological Awareness and Memory of Pseudowords. As for reading, according to the regression analysis, the total Phonological Awareness best explains the variation of performance.

Therefore, the results allow us to conclude that among the analyzed skills, phonological awareness presented the greatest independent contribution to performance, both in writing and reading, which supports the first hypothesis, which presupposed the predominance of metaphonological skills as predictors of literacy. In addition, in the assessment of phonological memory and rapid naming skills, the Memory of Pseudowords and RAN letters were the only ones that presented significant correlation with reading and writing skills, and in the case of writing performance, phonological memory also showed an independent and significant contribution, which is also in agreement with the initial hypotheses of the research.

However, important differences in the power of the models obtained for the explanation of performance in writing and reading occurred. While the Writing explanatory model explained $60 \%$ of the variability, the Reading model explained only $22 \%$. In fact, according to Frith (1985), there is dissociation between the processes and strategies used to read and write in the initial period of literacy. According to the author, there are indications that writing tends to rely on alphabetical strategies (grapheme-phoneme correspondences) before reading. Reading, in turn, would tend to automate before writing, relying less time on alphabetical strategies. According to this hypothesis, writing would be supported for longer under alphabetical strategies control, which are more dependent on phonological coding, thus explaining the greater contribution of phonological awareness and phonological memory skills to writing performance, at least at the literacy stage in which most of the research participants are likely to be inserted, whose reading skills must already be starting to automate.

Phonological Awareness, especially in its total score (syllables + phonemes), showed strong significant correlation with the Writing, being also moderately correlated to Reading, evidencing the importance of this skills in the beginning of reading and writing acquisition, corroborating the results of Brazilian studies that also found these relationships (Barrera \& Maluf, 2003; A. G. S. Capovilla, Gütschow, \& F. C. Capovilla, 2004). We also noticed that, although the correlations of phonemic awareness with reading and writing skills are higher than syllabic correlations, the last skill also play an important role for the Brazilian Portuguese learners, since the PA total score, which sums the points of the two types of task, contributed most significantly to the explanatory models elaborated for both writing and reading performances. This result differs from that found in the study by Melby-Lervag et al., (2012), which points to phonemic awareness as the best predictor of reading 
performance in English, as the syllabic skills would not cause an independent contribution to reading. Such a discrepancy in results may be due to phonological differences between languages, since the syllable is a more salient phonological unit in French and Portuguese than in English (Seymour, 2013).

Regarding the phonological memory, for both the Writing and Reading variables, significant correlations occurred with the Memory of Pseudowords. As for the Memory of Digits, there was a smaller correlation, but still close to significance, regarding Writing, but it was not correlated with Reading. Therefore, there is an apparent relation between phonological memory, especially when evaluated by tasks involving pseudowords, and reading and writing, reinforcing the results pointed out by Gindri, Keske-Soares and Mota (2007) and Kibby et al., (2004). Thus, we support the hypothesis that memory of pseudowords tests are more effective in assessing aspects of phonological memory, since the stimuli do not have semantic or sound characteristics that can activate semantic or phonological representations in long-term memory, being thus a more "pure" measure of phonological memory, as suggested by Snowling and Stackhouse (2004).

Visual Processing showed significant correlation with neither the Writing nor Reading, corroborating the findings of Capovilla et al., (2004). These results do not mean that visual processing skills are not important for learning to write and read, since other studies, such as Souza and Capellini (2011), show that students with learning disorders presented inferior performance compared to students with good academic performance, in relation to visual-motor coordination, position in space, copy, visual closure, visual-motor speed and form constancy skills. However, the fact that these authors used several tests that also measured visual-motor skills may have contributed to the differences in results. In addition, the tests applied in this research mainly deal with visual perception aspects, and it may be pointed out that other skills involved in visual processing, such as the breadth of letters processed at once, may be more relevant as predictors of reading performance, as suggested by Bosse and Valdois (2009).

With regard to the analyzes involving rapid automatized naming, the results are in line with the literature, with letter and digit naming tests being the most related to reading skills (Wolf \& Bowers, 1999). There were significant correlations from moderate to strong level among the four rapid automatized naming tasks. The fact that the RAN letters was, among the naming speed tests, the only one significantly correlated to reading and writing skills, it is probably related to the fact that the letter identification speed is an intrinsic part of reading and writing processes, which are based specifically on the processing of this type of stimulus.

On the other hand, it should also be considered that since most RAN tasks were not significantly correlated with reading and writing skills, or even that this index was only moderate, it may be because, in this research, reading was evaluated in terms of words and pseudowords decoding skills, while naming speed was more directly related to reading fluency skills, as reviewed by Navas, Pinto and Dellisa (2009). Wolf and Bowers
(1999) also stress the naming speed role as a predictor variable of fluency skills and reading comprehension.

Finally, considering the predictor variables correlations among themselves, all naming speed measures presented moderate to strong significant correlations. However, of the four RAN measures, only letters naming presented moderate correlation and statistically significant with phonological awareness measurements (PA syllables, PA phonemes and PA total); a weak correlation between RAN color and PA phonemes also occurred, therefore, with few correlations between the rapid naming tests and the other studied phonological processing measures, contrary to the hypothesis of Wagner and Torgesen (1987), which include naming speed as part of phonological processing skills. On the other hand, naming speed was also not correlated with visual processing skill, a hypothesis suggested by Wolf and Bowers (1999). The exploratory factor analysis corroborated these data, identifying three factors, one of them being more loaded with the Memory of digits, Total memory and PA total variables (which could correspond to the latent "phonological processing" factor), another more loaded factor of the RAN Letters, RAN digits, RAN colors, and RAN objects variables (this factor corresponding to the naming speed) and a third most loaded factor of the Visual Processing variable. Thus, the data of this study seem to agree with the results of the study by C. N. G. Justi, Roazzi, F. R. Justi, Henriques et al., (2014) that question the inclusion of RAN measures in phonological processing, suggesting that this is a skill more specifically related to the cognitive processing speed. Likewise, it was not possible to group RAN measures with Visual Processing skills, at least in the way they were evaluated in this research.

The results contribute to the understanding of the psychological processes involved in the learning of reading and writing, and can offer subsidies for the elaboration of more efficient literacy methodologies, related to the scope of teaching, as well as the prevention and remediation of learning difficulties. They can also support decisions about the skills to be considered in tests intended to investigate phonological processing.

Although our results support those obtained in the studies of C. N. G. Justi, Roazzi and F. R. Justi (2014) and Wolf and Bowers (1999), the nature of the processes for rapid naming was not investigated, only suggesting that the nature of these skills would not be properly phonological. Another limitation of this study is the reduced sample size to calculate the factorial analysis, since the number of participants, although reaching the minimum required for the analysis, was below the considered ideal to guarantee greater reliability of the results. Therefore, in future studies, a greater number of participants would be desirable. In addition, it is important to emphasize that the study evaluated only $3^{\text {rd }}$ year Elementary School children, so it would be interesting that the studied skills in this study be evaluated in a cross-sectional study, addressing different schooling levels or even in a longitudinal study, to follow the development of these skills with the education progress. 


\section{References}

Abdi, H. (2003). Factor rotations in factor analyses. In: M. Lewis-Beck, A. Bryman \& T.

Futing (Orgs.), Encyclopedia of social sciences research methods (pp. 1-8). Thousand Oaks, CA: Sage.

Barrera, S. D., \& Maluf, M. R. (2003). Consciência metalinguística e alfabetização: Um estudo com crianças da primeira série do ensino fundamental [Metalinguistic awareness and literacy: A study carried out among first elementary grade children]. Psicologia: Reflexão e Crítica,16(3), 491-502. doi:10.1590/S010279722003000300008

Bicalho, L. G. R., \& Alves, L. M. (2010). Nomeação seriada rápida em escolares com e sem queixa de problemas de aprendizagem em escola pública e particular [The rapid serial naming in students with and without complaints of learning problems in public and private schools]. Revista CEFAC, 12(4), 608-616. doi:10.1590/S151618462010005000018

Bogossian, M. A., \& Santos, M. J. (1977). Teste Illinois de habilidades psicolinguísticas [Illinois test of psycholinguistic abilities]. Rio de Janeiro, RJ: EMPSI.

Bosse, M.-L., \& Valdois, S. (2009). Influence of the visual attention span on child reading performance: A crosssectional study. Journal of Research in Reading, 32(2), 230-253. doi:10.1111/j.1467-9817.2008.01387.x

Capellini, S. A., \& Lanza, S. C. (2010). Desempenho de escolares em consciência fonológica, nomeação rápida, leitura e escrita [Student's performance in phonological awareness, rapid naming, reading and writing]. PróFono Revista de Atualização Científica, 22(3), 239-24. doi:10.1590/S0104-56872010000300014

Capellini, S. A., Oliveira A. M., \& Cuetos, F. (2010). PROLEC: Provas de avaliação dos processos de leitura [PROLEC: Assessment tests of reading processes] (2nd ed.). São Paulo, SP: Casa do Psicólogo.

Capovilla, A. G. S., Gütschow, C. R. D., \& Capovilla, F. C. (2004). Habilidades cognitivas que predizem competência deleituraeescrita[Cognitiveskillsthatpredictcompetencies in reading and writing]. Psicologia: Teoria e Prática, 6(2), 13-26. Retrieved from http://pepsic.bvsalud.org/scielo. php?script=sci_arttext\&pid=S1516-36872004000200002 \&lng $=\mathrm{pt} \& \operatorname{lng}=\mathrm{pt}$

Cohen, J. (1988). Statistical power analysis for the behavioral sciences (2nd ed.). New Jersey: Lawrence Erlbaum

Cunha, V. L. O., \& Capellini, S. A. (2011). Habilidades metalinguísticas no processo de alfabetização de escolares com transtornos de aprendizagem [Metalinguistic skills in the literacy process of children with learning disorders]. Revista Psicopedagogia, 28(85), 8596. Retrieved from http://pepsic.bvsalud.org/scielo. php?pid=S0103-84862011000100009 \&script=sci_arttext
Damásio, B. F. (2012). Uso da análise fatorial exploratória em psicologia [Uses of exploratory factorial analysis in psychology]. Avaliação Psicológica, 11(2), 213228. Retrieved from http://pepsic.bvsalud.org/scielo. php?script=sci_arttext\&pid=S1677-04712012000200007 $\& \operatorname{lng}=\mathrm{pt} \&$ tlng $=\mathrm{pt}$

Denckla, M. B., \& Rudel, R. (1974). Rapid “automatized" naming of pictured objects, colors, letters and numbers by normal children. Cortex, 10(2), 186-202.

Ehri, L. (2013). O desenvolvimento da leitura imediata de palavras: Fases e estudos [Development of sight word reading: Phases and findings]. In M. Snowling \& C. Hulme (Orgs.), A ciência da leitura [The science of reading] (R. C. Costa, Trans., pp. 153-172). Porto Alegre, RS: Penso.

Ferreira, T. L., Capellini, S. A., Ciasca, S. M., \& Tonelotto, J. M. F. (2003). Desempenho de escolares leitores proficientes no teste de nomeação automatizada rápida - RAN [The rapid serial naming in students with and without complaints of learning problems in public and private schools]. Temas sobre Desenvolvimento, 12(69), 26-32.

Evans, J. D. (1996). Straightforward statistics for the behavioral sciences. Pacific Grove, CA: Brooks/Cole Publishing.

Frith, U. (1985). Beneath the surface of developmental dyslexia. In K. Patterson, J. Marshall \& M. Coltheart (Orgs.), Surface dyslexia: neuropsychological and cognitive studies of phonological reading (pp. 301-330), Londres: L. E. Associates.

Gathercole, S. E., \& Baddeley, A. D. (1993). Working memory and language. Hove, United Kingdom: Psychology Press.

Germano, G. D., Pinheiro, F. H., Padula, N. A. M., Lorencetti, M. D., \& Capellini, S. A. (2012). Desempenho em consciência fonológica, nomeação rápida, leitura e escrita em escolares com dislexia secundária a retardo mental e com bom desempenho acadêmico [Performance in phonological awareness, rapid naming, reading and writing in students with secondary dyslexia to mental retardation and with good academic performance]. Revista CEFAC, 14(5), 799807. doi:10.1590/S1516-18462011005000140

Gindri, G., Keske-Soares, M., \& Mota, H. B. (2007). Memória de trabalho, consciência fonológica e hipótese de escrita [Working memory, phonological awareness and spelling hypothesis]. Pró-Fono Revista de Atualização Científica, 19(3), 313-322. doi:10.1590/S0104-56872007000300010

Hammil, D. D., Pearson, N. A., \& Voress, J. K. (2001). Teste evolutivo de percepção visual [Developmental teste of visual perception] (2nd ed.). Rio de Janeiro, RJ: Entreletras.

Justi, C. N. G., Roazzi, A., \& Justi, F. R. (2014). São as tarefas de nomeação seriada rápida medidas do processamento fonológico? [Are rapid automatized naming tasks measures of phonological processing?]. Psicologia: Reflexão e Crítica, 27(1), 44-54. doi:10.1590/S010279722014000100006 
Justi, C. N. G., Roazzi, A., Justi, F. R., Henriques, F. G., \& Cançado, M. F. L. (2014). Três hipóteses sobre a natureza das tarefas de nomeação seriada rápida [Three hypotheses on the nature of rapid automatized naming tasks]. Psicologia: Teoria e Pesquisa, 30(4), 449-457. Retrieved from http:// www.scielo.br/scielo.php?script=sci_arttext\&pid=S010237722014000400010\&lng=pt\&tlng=pt

Justino, M. I. S. V., \& Barrera, S. D. (2012). Efeitos de uma intervenção na abordagem fônica em alunos com dificuldades de alfabetização [Effects of a phonics intervention in students with difficulties in literacy]. Psicologia: Teoria e Pesquisa, 28(4), 399-407. doi:10.1590/S0102-37722012000400009

Kibby, M. Y., Marks, W., Morgan, S., \& Long, C. J. (2004). Specific impairment in developmental reading disabilities: A working memory approach. Journal of Learning Disabilities, 37(4), 349-363. doi:10.1177/002221940403 70040601

Melby-Lervag, M., Lyster, S. A. H., \& Hulme, C. (2012). Phonological skills and their role in learning to read: A meta-analytic review. Psychological Bulletin, 138(2), 322-352. doi:10.1037/a0026744

Moojen, S., Lamprecht, R., Santos, R. M., Freitas, G. M., Brodacz, R., Siqueira, M., ... Guarda, E. (2007). CONFIAS - Consciência fonológica: Instrumento de avaliação sequencial [CONFIAS - Phonological awareness: Sequential evaluation instrument] (2nd ed.). São Paulo, SP: Casa do Psicólogo.

Navas, A. L. G. P., Pinto, J. C. B. R., \& Dellisa, P. R. R. (2009). Avanços no conhecimento do processamento da fluência em leitura: Da palavra ao texto [Improvements in the knowledge of the reading fluency processing: From word to text]. Revista da Sociedade Brasileira de Fonoaudiologia, 14(4), 553-559. doi:10.1590/S151680342009000400021

Seabra, A. G., \& Dias, N. M. (2012). Avaliação neuropsicológica cognitiva: Linguagem oral [Cognitive neuropsychological assessment: Oral language]. São Paulo, SP: Memnon.

Seabra, A. G., Dias, N. M., \& Capovilla, F. C. (2013). Avaliação neuropsicológica cognitiva: Leitura, escrita e aritmética [Cognitive neuropsychological assessment: Reading, writting and arithmetic]. São Paulo, SP: Memnon.

Seymour, P. H. K. (2013). O desenvolvimento inicial da leitura em ortografias europeias [The early reading development in European spellings]. In M. Snowling \& C. Hulme (Orgs.), A ciência da leitura [The science of reading] (R. C. Costa, Trans., pp. 314-333). Porto Alegre, RS: Penso.
Snowling, M. J., \& Stackhouse, J. (2004). Dislexia, fala, linguagem: Um manual do profissional [Dyslexia, speech and language: A practitioner's handbook] (M. F. Lopes, Trans). Porto Alegre, RS: Artmed.

Souza, A. V., \& Capellini, S. A. (2011). Percepção visual de escolares com distúrbios de aprendizagem [Visual perception of students with learning disabilities]. Revista Psicopedagogia, 28(87), 256261. Retrieved from http://pepsic.bvsalud.org/scielo. php?script=sci_arttext\&pid=S0103-84862011000300006 \&lng $=$ pt\&tlng $=\mathrm{pt}$

Wagner, R. K., \& Torgesen, J. K. (1987). The nature of phonological processing and its causal role in the acquisition of reading skills. Psychological Bulletin, 101(2), 192-212. doi:10.1037/0033-2909.101.2.192

Wolf, M., \& Bowers, P. G. (1999). The doubledeficit hypothesis for the developmental dyslexias. Journal of Educational Psychology, 91(3), 415-438. doi:10.1037/0022-0663.91.3.415

Gabriela Guarnieri Mendes holds a Master's degree in Psychology from Faculdade de Filosofia, Ciências e Letras de Ribeiro Preto of the Universidade de São Paulo.

Sylvia Domingos Barrera is a Professor of the Faculdade de Filosofia, Ciência e Letras de Ribeirão Preto of the Universidade de São Paulo.

Received: Oct. 3, 2015

1st Revision: Apr. 11, 2016

Approved: Apr. 11, 2016

How to cite this article:

Mendes, G. G., \& Barrera, S. D. (2017). Phonological processing and reading and writing skills in literacy. Paidéia (Ribeirão Preto), 27(68), 298-305. doi: 10.1590/1982-43272768201707 